\title{
Reflections on Teaching Referencing: What Four Case Studies Can Tell us About Developing Effective Teaching Strategies
}

\section{Theresa Hyland}

Two contradictions are inherent in our research into referencing practices and the subsequent development of teaching strategies to remedy inappropriate practices. First, aggregate studies and teaching strategies that tend toward a one-size-fitsall formula for researching and teaching referencing do not consider individual differences in students' development of the complex set of skills that we know are involved in referencing practice. Further, although we say that we want students to be creative in their reading and writing practices, our teaching encourages them to look for correct answers in their reading of sources and to imitate set formulae for writing essays. This article examines four case studies taken from a larger aggregate study of EL1 and EL2 students. In their interviews and essay scripts, these students show varying levels of awareness of appropriate referencing practices. After examining these differences, I adapted Ada's (Cummins, 1996) framework for comprehensible input and critical literacy, as well as work by Hinkel (2002), Keck (2006), and Kintsch (1998), to develop some strategies for teaching referencing that address individual differences.

Deux contradictions sont inhérentes à notre recherche sur les pratiques de référence et le développement subséquent de stratégies d'enseignement visant la correction de pratiques inappropriées. D'abord, les études et les stratégies d'enseignement globales qui tendent vers une formule "taille unique » pour les pratiques de référence en recherche et en enseignement ne tiennent pas compte des différences individuelles dans le développement chez les élèves de l'ensemble d'habiletés complexes qui sont impliquées dans les pratiques de référence. Deuxièmement, même si on maintient que nous voulons que les élèves soient créatifs dans leurs lectures et leurs rédactions, notre enseignement les encourage à chercher les bonnes réponses en consultant les sources et à imiter des formules établies quand ils écrivent. Cet article examine quatre études de cas puisés d'une plus grande étude combinée portant sur des élèves d'ALP et d'ALS. Les transcriptions des entrevues et des dissertations de ces élèves démontrent des niveaux variés quant à la conscience des pratiques de référence appropriées. Suivant l'étude de ces différences, l'auteure a adapté le cadre de Ada pour l'input compréhensible et la littératie critique, ainsi que le travail de Hinkel (2002), Keck (2006) et Kintsch 
(1998) pour développer des stratégies en enseignement des pratiques de référence qui tiennent compte des différences individuelles.

\section{Introduction}

In an article in TESL Contact entitled "EAP Writing Instruction: ESL perspectives on content issues and teacher knowledge," Cummings (2007) talks about how teachers learn while they are teaching. She states that they learn from their communities of practice, from their students, and from reflection on their practices. They engage in this learning when they attend conferences, read papers, engage in listserv discussions, create new strategies, or design new courses. As a writing teacher, I too reflect on my own practice (or the what of what I do), but also as a writer or performer of what I teach, I often reflect on the why of what I do: the personal, intellectual, classical traditions that affect my choice of strategies and techniques. The research study in which I recently engaged led me to question why some English-asa-first language (EL1) and English-as-a-second-language (EL2) students perform better in referencing practices than others. In this article I examine four representative cases from the larger study in order (a) to fine-tune our understanding of why individual students learn referencing practices at their own pace, and (b) to show how research that compares EL1 and EL2 students' learning can lead to the design of effective strategies for teaching Western academic referencing practices to both groups of students.

\section{Inherent Contradictions in Our Teaching and Research}

Several researchers have investigated plagiarism and referencing strategies of EL1 and EL2 students (Abasi \& Akbari, 2008; Campbell, 1990; Howard, 1999; Keck, 2006; Shi, 2004). However, an examination of written scripts and interviews with students can tell us only what students have not learned through current teaching strategies. They tell us that although students are aware of the penalties of plagiarism, they do not understand how to avoid it. The document on plagiarism contained in most course outlines is read to students on the first day of term and again when each assignment is handed out; the handouts that show how to bound (separate) and document (cite sources) of references; the one-size-fits-all workshops on proper documentation practice do not seem to help students avoid plagiarism in their writing. Indeed, with universal Internet access to sources of information including peer-reviewed journals, students seem to view all information as common knowledge and are even less inclined to cite sources (Randall, 2001).

There are inherent contradictions in our teaching of writing. First, the more we teach students the rules of reading and writing, the less we allow them to develop as critical thinkers. Generic rules of reading (e.g., look for the thesis in the essay and the sub-arguments that support it) and writing 
(e.g., the ubiquitous hamburger essay) inhibit students' ability to solve the problems of reading and writing in more complex ways. When they are writing, their adherence to formulae becomes more important than the expression of complex ideas. When they are reading articles, they neglect the context of the argument and the assumptions that underpin it in favor of a recitation of the facts presented in the piece. Abasi and Akbari (2008) note that although faculty believe that their comments on writing assignments and course outlines seem to encourage academically sound writing and referencing practices, these "rules" encourage students to reproduce authority rather than to produce it. Further, the way professors speak about the writing that students must complete can intimidate them and inadvertently encourage patchwriting. In my own practice, I have noticed that when students read for class, they look for one right answer that they think I want them to gather from the reading. It is only natural, then, that if they use this reading in an essay, they repeat the author's words in order to convey the idea accurately.

The second contradiction is that learning good referencing practice is related to individual growth in thinking skills, yet many researchers examine the problem of faulty referencing practice through aggregate studies, and teachers develop strategies that address trends rather than individual development. Notwithstanding these trends in research and curriculum development, some research in cognitive development supports the idea that people develop critical thinking skills at their own pace and that these critical thinking skills are directly related to acceptable referencing practices. Bereiter and Scardamalia (1989) examined the role of intentional learning as the goal of instruction and concluded that students who write about what they have researched tend toward knowledge-telling: they tell the reader what they have understood from their reading. Knowledge-creation, or the ability to synthesize and evaluate sources, comes at a later stage in students' development. Howard (1993) expanded on this idea with the notion of patchwriting by which she asserts that students not only tell the reader the ideas that they have read, but they also use the same words as the source because they cannot find their own words to convey these new and complex ideas. Howard (1999) argued that as students become more skilled at conveying complex ideas in their own words, they patchwrite less. Howard and Bereiter and Scardamalia see this as a problem of individual growth. Not surprisingly, then, Roessingh and Kover (2003) call for a move from identifying general trends in student behavior to understanding how each person's development of higher-order thinking skills interacts with his or her language development.

How we incorporate others' ideas into spoken or written language depends on the cultural and linguistic mechanisms of the language that we are speaking. Bakhtin and Voloshinov (1929/1973), in Marxism and the Philos- 
ophy of Language, asserted that reported speech is "an objective document of [the] ... active reception of another speaker's speech" (Morris, 1994, p. 63). Yet the language used in that objective document, "exists on that creative borderzone or boundary between human consciousness, between a self and an other" (p. 5). Learning, according to Bakhtin and Voloshinov, takes place through a dialogue between the microcosm of the self and the macrocosm of the social, so that "the individual consciousness is a socio-ideological fact" (p. 52). Writing is the externalization of an inner dialogue, but if the external and internal dialogues proceed in different languages and cultures, then the problem of citation practice is further complicated. Cumming (1990) asserted that linguistic knowledge affects the ability of students to think abstractly about their writing. Hinkel (2002), in a massive study of the rhetorical and linguistic features of EL1 and EL2 writers' written texts, found that EL1 students had fewer linguistic and rhetorical tools to indicate a separation of their ideas from those of the source they were paraphrasing. Barriers to increased fluency in a second language compound the cultural effects of different expectations of the separation of source material from the writer's own material.

The reason for the failure of most anti-plagiarism talks, workshops, and handouts, then, is that we have not resolved these two contradictions in our research and subsequent development of teaching strategies. In this article, I discuss the performance of four people (2 EL1 and 2 EL2) who were part of a larger study that explored the differences in referencing practices between EL1 and EL2 students. These four students seem to belong to the four stages of understanding about bounding and documenting references. I then propose some teaching strategies designed to address their individual stages in the development of critical thinking skills and their ability to reference sources appropriately.

\section{The Research Study}

In an aggregate research study, I adopted Bakhtin's (1923, in Morris, 1994) ideas of direct (D), quasi-direct (QD), quasi-indirect (QI), and indirect (I) speech and combined these with the Western academic notion that in writing, sources must be bounded (B), separated from our own ideas and documented (D), or source identified. I used these notions to develop a grid containing 16 possible reference types (see Appendix A for a complete list of reference types used in the study). For example, direct citations could be fully documented and bounded (DDB); documented but not bounded (DDU); bounded but not documented (DUB); and neither documented nor bounded (DUU). Quasi-direct citations were defined as close paraphrases (i.e., Howard's, 1993, notion of patchwriting), which could also fall into each category. Quasi-indirect citations were defined as loose paraphrases; summaries of ideas were defined as indirect citations. Although all these types of 
citations are acceptable means of incorporating ideas from a source into an academic text, North American academic practice dictates that they must all be fully documented and bounded. The Reading Reference Grid allowed me to examine the kinds of referencing that both EL1 and EL2 students use in their essays and how well these types of references were both bounded and documented.

I examined the written scripts of 96 EL1 students and 29 EL2 students who wrote a 500-word timed essay on the subject of animal preservation versus human use of resources. They wrote the essay in response to reading "The Elephant War," an article on the CAMPFIRE project by Richards (1996). I examined each script for the number of references that fell into each of the 16 reference categories. Interrater reliability for agreement in coding references identified on a subset of the written scripts was $r=.9$ using the Pearson coefficient. When I completed this catalogue, I interviewed 41 of the students who had written the essays (27 EL1 and 14 EL2) about their referencing practices. The interviews used some set questions to stimulate discussion, but students also had both their written scripts, which had been typed and highlighted using text replication software, and the reading prompt as further stimuli for the discussion (Hyland, 2009).

In order to identify trends in the frequency and quality of references that each written script contained, I created an Acceptable Referencing Index (ARI, see Appendix B for a sample calculation) by assigning values to the various categories of referencing counted in the Reading References Grid, and worked out the average value of references per written script. The values were assigned according to the closeness of each reference type to established North American academic practice. Because writing in North American academic contexts should be both bounded and documented according to source (Howard, 1999; Shi, 2004), all bounded and documented references were assigned the highest value of 3 . Instances of partial documentation and bounding (either bounding but no documentation or documenting but no bounding) show some capacity to distinguish authorial and source texts, although these are still considered by many as plagiarism (Howard, 1999). I considered such instances as indicating some understanding of referencing and so assigned them a value of 2 . Finally, I assigned the presence of a source reference that lacked documentation and bounding a value of 1 . The average of these values per paper, then, was intended to indicate students' relative ability to apply appropriate referencing practice consistently. An average score of 1 showed the presence of references, but no awareness of bounding and documenting practice; an average in the range of 1.1-1.5 showed some awareness of bounding and documenting practice; an average of 1.6-2 showed appropriate but inconsistent use of bounding and documenting strategies; and an average higher than 2 showed a high level of consistency in using bounding and documenting strategies. When I assigned 
Table 1

Acceptable Referencing Index (ARI)

\begin{tabular}{lcccccccc}
\hline Average Range & 1 & $1.1-1.5$ & $1.6-2$ & $2.1-2.5$ & $2.6-3$ & Total & $M$ & $S D$ \\
\hline $\begin{array}{l}\text { Frequency for } \\
\text { whole group }(N=125)\end{array}$ & 17 & 60 & 42 & 6 & 0 & 125 & 1.45 & .34 \\
$\begin{array}{l}\text { Frequency for } \\
\text { EL1 }(N=96)\end{array}$ & 12 & 47 & 31 & 6 & 0 & 96 & 1.5 & .35 \\
$\begin{array}{l}\text { Frequency for } \\
\text { EL2 }(N=29)\end{array}$ & 5 & 13 & 11 & 0 & 0 & 29 & 1.4 & .31 \\
\hline
\end{tabular}

the ARI values to all the written scripts for EL1 and EL2 students, I found a similar frequency curve for both sets (see Table 1). For each set the highest number of papers fell in the 1.1-1.5 and 1.6-2 ranges, with some EL1 students scoring at both the upper and lower ranges and some EL2 students scoring at the lower range, but no students scoring in the upper range.

All this information helps us to identify trends in students' referencing practices, but does not help us draw conclusions about why individuals vary in their ability to apply referencing practices to their own writing. In order to gain this individual perspective, I randomly chose four students, two EL1 and two EL2, whose ARI scores placed them in separate categories in terms of expertise in referencing. For each student I looked at the ARI, the context of the references in the written script, and the tapescripts of the interviews where the students talked about their referencing strategies.

The four students (all identified by pseudonyms) were:

1. Frank, an 18-year-old EL1 student who had been in university for about two weeks when he wrote the essay based on "The Elephant War." He had 21 references in his written script, but all were undocumented and unbounded, and so he scored an ARI of 1 for his references.

2. Lucy, an EL2 student who had been in Canada for about two years, but had only just entered university when she wrote the essay. All her references were unbounded and undocumented except for one partial citation. She had an average score of 1.4 on the seven references she made to the reading.

3. Charles, an EL2 student who had studied in Canada for two and a half years and had been in university for one full year when he wrote the essay for my research. Charles made 20 references to the reading and had an Acceptable Referencing Index of 1.8. This score shows that many of his references were either partly or fully bounded and documented. Indeed, only eight of these references showed no bounding or documenting.

4. Janice, an EL1 student. Janice was a 17-year-old Canadian who was registered in a first-year humanities program. She scored an average of 
2.2 on her nine references: five were documented and bounded, and only two were unbounded and undocumented.

\section{Findings}

Frank asserted almost immediately in the interview that he knew nothing about the issue that the reading addressed, so he had to rely on the information from the reading as fact. He also indicated that he agreed with the information that he took from the reading and picked out only those points that supported his opinion. Frank spent much of the interview discussing the rhetorical strategies that he could use to separate his ideas from those of the reading, but on at least two occasions he indicated that he believed that when he changed the words from those of the reading or drew inferences from it, those ideas became his own. At one point, he asserted that his thesis was "a little bit different" from Richards' thesis. When asked, "How do you make a distinction between the two?" he said, "Between my idea and their idea? Well, because without the program they would not have very many options, so I just drew the inference that." For him, drawing an inference required no statement of from whose idea he was drawing an inference. When asked why there were no quotes in his writing, he offered two explanations: (a) he was in a hurry, (b) he said that much of the article was stated "in a factful way."

In her interview, Lucy disagreed with the main idea of the reading and wished to show this disagreement in her writing. "My thesis is disagree," she said at several points in the interview. She explained how she went through the article and underlined many things that she thought she could use, but she did not use everything that she underlined because some points did not fit with her argument. Like Frank, Lucy made several comments about the rhetorical strategies that she could use in her essay to separate her ideas from those of the author of the reading. For example, she said at one point, "Ah, if I change to my words I ... I have to write down where I find it?" Lucy also asserted that she was taught not to use other people's ideas in her writing because this was plagiarism. Rather, she should put their ideas into her own words, and then she could write them in her essay, presumably without citation. Her final question was about how she could remember vocabulary more easily.

Charles expressed prior knowledge of the issues presented in the reading and wished to explain his own ideas about the issues to the interviewer. He said that he used ideas from the reading to support his own ideas and consciously chose ideas with which he agreed. He also mentioned that he took quotes in order to express a complete idea from the reading rather than simply paraphrasing the idea and taking it as his own. He expressed the insight that he needed to give more examples from his own experience. When the interviewer asked why he had incorporated ideas into his text, 
Charles simply recounted what the reading said. He was preoccupied with essay-format questions, particularly in formulating his introduction and conclusions. He asked the interviewer, "How about the last two paragraphs?" Finally, he declared that he should repeat the introduction in the conclusion "for emphasis."

Janice's writing showed a good understanding of the conventions of bounding and documenting sources, but her interview confirmed that even students who think with this level of sophistication still have something to learn about incorporation of research into their essays. Janice spent the first five minutes of the interview agonizing over plagiarism, and her method of avoiding it, which was basically to paraphrase a reading rather than quoting it word for word. At the same time, however, her explanation of how she went about absorbing information from a reading was a good example of the struggle that all students undergo to keep ideas from the reading separate from their own ideas:

And so, my thought pattern will go along with it ... but then my thought pattern will focus on a phrase that I heard right.... and I won't realize it ... until I put it onto the paper ... and then I'll be like, "Oh, that phrase is in it." So I have to keep reminding myself, "Don't put the same phrase as you're thinking in it ... be sure you go over it and make sure" ... 'cause sometimes I'll back up my thoughts by saying something and I'll forget to put the quotation marks in because I'll be thinking my own thoughts and not the essay's.

The struggle that she referred to is, I think, the struggle to understand ideas from sources and to find her own voice in expressing them. Janice understood the value of quotes as indicating which areas of the article show the reader "exactly what you're coming from." Through the conversation engendered by the interview, she seemed to gain the insight that quotes actually supported an argument rather than told the argument. She said, "OK, so you're saying that taking actual quotes from the previous essay and writing about them would help strengthen it? ... I didn't know that."

Like Charles, Janice knew about the environmental issues that were discussed in the article. During the interview, she related three episodes in her own life that had strongly shaped her attitudes toward preserving and/or conserving nature. She was excited to be able to agree with the arguments in the article. She said, "And that's something that I agree ... it was like ... Wow, it was nice that they finally found a way." Commenting on the time limits of the essay, she expressed the need to digest information before she used it in an essay. She said, "I usually take a day or so ... but I mean it's not ... it's bits and pieces throughout the day thinking about it." Like Frank, Lucy, and Charles, Janice asked about the proper location of her thesis statement in the essay and about whether the markers of the assessment 
looked for accuracy in grammar and spelling. Only one question was concerned with the development of the argument of the essay: she asked whether the inclusion of a personal experience would strengthen her argument.

\section{Discussion}

In his interview, Frank shows his ability to understand and paraphrase the reading, but also a tendency to recite what he has learned from the reading rather than to analyze or evaluate it (knowledge-telling). Frank believed the argument of the reading was true, and that he could, therefore, draw on it as if from common knowledge. This was accompanied by a preoccupation with the rules of writing. He spent much of the interview trying out rhetorical strategies that would separate his ideas from those of the reading and made comments about his own poor grammar when looking at the writing. His one question to me in the interview was about whether he could say $I$ in the essay because he had been taught that this was poor academic practice. Frank's tendency toward knowledge-telling along with his concern with the grammatical features of his writing were good indications of his stage of thinking about incorporating research into his own writing. His inability to understand that the text represented a point of view about the issues concerned with animal preservation meant that he could not move from knowledge-telling to knowledge-transformation. It also meant that he could not distinguish what he thought about the issue from what the article said: they were one and the same; so there did not seem to be a need to bound and document references to the text.

Lucy displayed some higher-level thinking skills in that she disagreed with the main premise of the article. Her technique of underlining and then choosing which argument to use showed a more analytic approach to the reading than Frank's. She clearly understood how the arguments for and against the thesis were developed. However, Lucy's comments showed that she was not clear about the difference between paraphrasing and quoting. This confusion translates into faulty referencing practice, hence her concern with rhetorical strategies rather than knowledge-transforming techniques. Although Lucy understood principles of analysis and evaluation of the ideas in a reading, these had not yet transformed into writing strategies. She seemed to need both reassurance to include her critical analysis in her writing and a repertoire of techniques that would help her distinguish her ideas from those of the reading.

Charles' prior knowledge of the issues allowed him to adopt a critical stance toward the ideas presented in the reading. His concern for higherlevel thinking skills was reflected at several stages in the interview. He was able to move from the it's a fact kind of statements that Frank made, to I agree with this opinion statements. Unlike Lucy, Charles also used ideas with which 
he disagreed in his writing, and there was some knowledge-creation when he attempted to synthesize his own thinking with that of the text and understand why he disagreed with some of its arguments. Despite many comments that showed a concern with ideas synthesis and critique, many others showed a concern with getting the form and the language correct. He also lacked the confidence to put his own ideas into the formal academic essay. These areas clearly needed development.

Janice's performance was a result of her ability to distance herself critically from the reading in order to evaluate its effectiveness. She was able to maintain a critical distance from the reading because she had much personal and theoretical experience with environmental concerns. However, her struggle constantly to remind herself which phrases came from the reading demonstrated the academic dilemma that many students face, which explains why they fail to document paraphrases. Despite her understanding of the purpose and uses of referencing in her writing, she was surprised that her personal experience could provide a valuable context in which to view the reading critically. Like Charles, Janice needed to develop the confidence to express her own ideas in an academic context, and although she was more successful in documenting and bounding her references, she still struggled with this process. Many of her questions also focused on essay format and grammar concerns.

Ada's (1996) framework of comprehensible input and critical literacyreproduced in Cummins' (1996) book Negotiating Identities-postulates that students understand their reading on several levels: descriptive, personal-interpretive, critical analysis, and creative action. Similarly, Segev-Millar (2004) noted that "discourse synthesis" or the "hybrid task of... comprehension and production" (p. 5) in students' writing requires explicit instruction. She asserts that summarizing a task is only the first step in the process and that knowledge-transforming requires that students create their own macropropositions from various propositions in the texts that they read. Hinkel (2002) concluded her research study, which compared NNS and NS written texts, with the assertion that,

first year NS students with only high school training in writing and composition have access to far greater ranges of syntactic structures, vocabulary, and collocations than even trained and highly advanced NNS's, most of whom are holders of U.S. academic degrees. (p. 257)

Given that all four students asked for more rhetorical strategies and vocabulary with which to separate and reference their sources, we cannot ignore this aspect of referencing training either. So the question becomes: How do we give explicit instruction for reading and referencing in writing without having the students become hidebound in their pursuit of rules for format and 
vocabulary, and how do we develop strategies that allow students to work at their own level of understanding?

\section{Implications for Teaching}

The case studies indicated individual differences in three areas that influence how students cite references in their writing: (a) in interpretation of the source article and how students located important points in it; (b) in how each student used the source article to support arguments; and (c) in how each student combined his or her own ideas with the ideas from the source just read.

These differences lead to implications for teaching referencing: (a) To teach referencing, one must teach both good reading and good writing practices (Grabe, 2001). (b) Students must be taught that agreeing with an argument does not mean simply repeating the argument. (c) Judgments about the sources must be based on an understanding of one's own values and those embedded in the reading. (d) Teaching and evaluation strategies for referencing must employ a complex set of strategies that acknowledge students' weaknesses in both rhetorical practices and higher-level thinking. Practically, strategies must be efficient in giving students rhetorical strategies that they can use to differentiate referenced ideas from their own; must create situations that allow students to practice these skills in isolation and in progressively more complex combinations; and must challenge students to move from one level of practice to a more effective level as their abilities improve.

I used Ada's (Cummins, 1996) four stages of understanding of readings as a framework in which to develop exercises to help students gain control of their referencing skills when they wrote about their research. I have used these exercises in a for-credit writing class that contains both freshmen and transfer third-year university students. I have found that the exercises help individual students to progress in referencing expertise no matter what level of referencing and critical thinking about sources they possess when they enter the class.

\section{Describing and paraphrasing a reading}

First, students must understand and describe how the argument of the reading is constructed. Unfortunately, this description is often made by copying the words of the text. Howard (1999) asserted that patchwriting is "a move towards membership in a discourse community" (p. 7). In her study of summary writing where she compared EL1 and EL2 paraphrasing strategies, Keck (2006) identified four types of paraphrases: near copy, minimal revision, moderate revision, and substantial revision. She noted that EL2 students tended to have more "near copies" than EL1 students, and fewer "moderate and substantial revisions" (p. 274). In order to move students' 
summary writing from many near copies to substantial revision of ideas, I would suggest that students engage in propositional mapping (Kintsch, 1998). Have students work in pairs to underline the ideational structure of the reading, and write defining key words in the margin (i.e., thesis, first main idea, evidence, conclusion, etc.). This exercise frees them from wordby-word meaning-extraction and encourages them to see the ideational content of the reading (Cumming, 1990). This might help Frank understand the argument and counterargument of the reading. It could give Lucy practice in paraphrasing the argument, and it might perhaps give Charles the confidence to state with which parts of the argument he agreed or disagreed. Janice might stop worrying about paraphrasing as plagiarism and begin to document the structured argument of the reading. Howard (1999) also proposed a series of exercises to help students move from understanding the argument, to underlining unfamiliar words in the text, to writing the ideas of the text in their own words, to creating a proposition of their own about the issue. Students can develop their awareness of rhetorical and linguistic strategies for bounding and documenting sources at this descriptive stage by underlining the phrases in the reading that mark these distinctions. Charles and Janice might use this exercise to add to their vocabulary of separation; Frank and Lucy could begin to understand that these strategies are a necessary part of writing about the reading.

I have found that certain types of closed-book pop quizzes also help students find their own words to paraphrase the ideas of a text. I ask them to write one or two sentences on some aspect of the reading with the source text out of view. I ask them, for example, for a one-sentence statement of the main argument or the three important points contained in the reading, or the conclusion to which the author comes, or two or three examples given in the reading. Yamada (2003) examined college Web sites to tease out the qualities of good paraphrasing techniques. She found that many examples used deductive/inferential or analogic reasoning to explicate the ideas of the source. This paraphrase exercise would allow students to work at one of two levels of thinking: either the deductive/inferential or analogic level, or the knowledge-telling level. Although Frank and Lucy might struggle to find their own words to express the ideas of the text, Charles and Janice might tease out the complexities of the argument of the text, notice the subtleties of expression in the text, and express these complexities in their writing.

Howard (1999) reminded us that it helps if some of the texts are "too difficult" for some students, because it is in the struggle with these texts that "issues of patchwriting and reading comprehension emerge" (p. 142). Have students, in groups and on overheads, practice writing four- or five-sentence summaries of a too-difficult reading according to guidelines that you have set up for the summary. The work could be compared, and students could choose the best or score points for each guideline that has been fulfilled. 
Although individual students will come to this exercise with varied levels of expertise, all will be able to progress in their referencing practices.

\section{Incorporating a personal interpretation of a reading into writing}

The personal/interpretive elements of understanding a reading can be developed by having students answer questions such as: What are the values assumed in the argument? How can you relate these to what you have seen in other readings/movies/real-life situations in Canada? Have these values affected you in any way? Ask students to describe how these values differ from their own. Could this essay/short story have been written in Japan? China? Germany? If not, why not? What are the differences? Then have them complete statements that would help them formulate their own ideas about the text. I use phrases like That's not true because ... This is biased because ... Here are the problems with this... The underlying values that this represents are .... Such exercises would help Frank begin to develop and express ideas of his own about the sources and could help Lucy express her own feelings about the complexity of the source. Charles and Janice lacked the confidence (and the linguistic competence) to express their ideas, but these strategies could provide safe opportunities for practice.

Some exercises can help students create macropropositions by synthesizing their own values and observations with what they read. Personal interpretive views can be acknowledged by having students talk about the values they bring to their everyday life in Canada. Each value must be accompanied by a personal story that illustrates it and must be compared to values from their reading. Have students look at idioms like fair play or competitive edge or team spirit or sayings like The early bird gets the worm or Early to bed, early to rise. Students could then list and compare idioms or colloquialisms from their own culture and write a short journal piece on how Canadian values differ from or are similar to theirs. Students could also play the Values Game (Brown, 2000), where they write out a list of situations with four possible actions to be taken. Students would discuss possible solutions and then talk about the values that each action would represent. They could then write a piece comparing their ideas with case studies that they read in class. I have found Cummins' (2000) idea of an identity text useful. Students select poems, pictures, or readings that help them demonstrate their own identity and discuss them in class. They can write a journal entry discussing why these items are important to them and which aspect of their own identity these items recall. Any of these exercises would show Frank that all writing stems from a set of assumptions that will differ from reading to reading. Lucy could stop seeing each argument as bipolar, but rather as a complex maze of ideas with which a reader may partly agree. Charles might develop the confidence to state his opinions as different from those of the reading, and Janice could 
begin learning to synthesize arguments according to the set of values they demonstrate.

\section{Moving from knowledge-telling to knowledge creation}

Viewing the reading text as a series of propositions that can be broken down, conveyed in other words, and agreed with is only part of what we do when we reference others' work. Most essays require some critical analysis of the readings or the ability to make connections between apparently different ideas or issues. This critical analysis can be encouraged through what I call the relativity theory. Students should be encouraged to look for competing values in the same culture, for example, the competing values of capitalism (competitive edge; success is measured by profit; buyer beware; individual responsibility) and social democracy (social responsibility; government control, taking care of the underdog; level playing field) that manifest themselves in the movie Supersize Me (Spurlock, 2004). These competing values could be used to create macropropositions about the culture. If the class is split in half, each group could determine the value system underlying one of two readings on the same topic. In comparing macropropositions, students could provide evidence from the readings to support them.

Text modeling is a technique often favored by ESL students; so talking about the benefits and limitations of this technique would help students decide whether and when it is an appropriate strategy to use (see Yamada's, 2003, reference to Stolarek's, 1994, discussion of the benefits of text-modeling for ESL students.) Segev Miller (2004) suggests that process logs help students with discourse synthesis and give them a better knowledge of the metacognitive strategies that they use when writing. In these logs, students indicate how they wrote an essay and the strengths and weaknesses of the product that they created as a result of this process. Process logs could help students at lower skill levels understand the need for rhetorical strategies that separate their ideas from those of the reading. Charles did not feel he that could write these ideas in his text, and Janice was looking for the voice with which she could express these opinions. Logs could increase Janice's and Charles' understanding of their own repertoire of values and assumptions, give them the vocabulary they need to discuss complex ideas, and give them psychological permission to use this thinking in their essays. Frank and Lucy could learn about diverse epistemological systems and begin to express these differences in their journals, logs, or class discussions, although they might not immediately transfer these ideas to the incorporation of source references in their writing.

As teachers, we are often frustrated when students do not seem to learn what we have so carefully taught them. This seems to be a particular problem with referencing. It is not my purpose in this article to reveal revolutionary new teaching strategies, but rather to alert writing teachers to the variety of 
strategies that have already been developed (DeSena, 2007) and to make sense of how each strategy can affect diverse learners in varied ways. By identifying four stages in learning about referencing, and the skills that need to be developed in order for students to move between stages, I hope that I have provided some coherence and a rationale for how and why we teach referencing practices.

\section{The Author}

Theresa Hyland completed her EdD at the University of Toronto in 2005. She is currently the Director of Writing and Cross-cultural Services at Huron University College, where she administers the Writing Centre and the Exchange Programs and teaches writing courses to both EL1 and EL2 students. She is curently conducting research into the effectiveness of writing services in promoting student engagement.

\section{References}

Abasi, A., \& Akbari, N. (2008). Are we encouraging patchwriting? Reconsidering the role of the pedagogical context in ESL student writers' transgressive intertextuality. English for Specific Purposes, 27, 267-284.

Bereiter, C., \& Scardamalia, M. (1989). Intentional learning as a goal of instruction. In L.B. Resnick (Ed.). Knowing, learning and instruction: Essays in honor of Robert Glaser (pp. 361-392). Hillsdale, NJ: Erlbaum.

Brown, P. (2000). Ethics questionnaire. The write angle. Anjou. PQ: Les Éditions CEC.

Campbell, C. (1990). Writing with others' words: Using background reading text in academic compositions. In B. Kroll (Ed.), Second language writing: Research insights for the classroom (pp. 211-230). New York: Cambridge University Press.

Cumming, A. (1990). Metalinguistic and ideational thinking in second language composing. Written Communication, 7(2), 482-511.

Cummings, J. (2007). EAP writing instruction: ESL teacher perspectives on content issues and teacher knowledge. Contact, 33(2), 46-70.

Cummins, J. (1996). Negotiating identities: Education for empowerment in a diverse society. Toronto, ON: CABE.

Cummins, J. (2000). Language, power, and pedagogy: Bilingual children in the crossfire. Clevedon, UK: Multilingual Matters

DeSena, L.H. (2007). Preventing plagiarism: Tips and techniques. Urbana, IL: NCTE.

Grabe, W. (2001). Reading-writing relations: Theoretical perspectives and instructional practices. In D. Belcher \& A. Hirvela (Eds.), Linking literacies: Perspectives on L2 reading-writing connections (pp. 15-47), Ann Arbor, MI: University of Michigan Press.

Hinkel, E. (2002). Second language writers' text: Linguistic and rhetorical features. Mahwah, NJ: Erlbaum.

Howard, R.M. (1993). A plagiarism pentimento. Journal of Teaching Writing, 11(2), 233-245.

Howard, R.M. (1999). Standing in the shadow of giants: Plagiarists, authors, collaborators. Stamford, CT: Ablex.

Hyland, T. (2009). Drawing a line in the sand: Identifying the borderzone between self and other in EL1 and EL2 citation practices. Assessing Writing, 14, 62-74.

Keck, C. (2006). The use of paraphrase in summary writing: A comparison of L1 and L2 writers. Journal of Second Language Writing, 15, 261-278.

Kintsch, W. (1998). Comprehension: A paradigm for cognition. Cambridge, UK: Cambridge University Press.

Morris, P. (Ed.). (1994). The Bakhtin reader: Selected writings of Bakhtin, Medvedev and Voloshinov. New York: Edward Arnold. 
Randall, M. (2001). Pragmatic plagiarism: Authorship, profit and power. Toronto, ON: University of Toronto Press.

Richards, A. (1996). The elephant war. Utne Reader, 78, 13-15.

Roessingh, H., \& Kover, P. (2003). Variability of ESL learners' acquisition of cognitive academic language proficiency: What can we learn from achievement measures? TESL Canada Journal, 21(1), 1-21.

Segev-Miller, R. (2004). Writing from sources: The effect of explicit instruction on college students' processes and products. L1-Educational Studies in Language and Literature, 4, 5-33.

Shi, L. (2004). Textual borrowing in second-language writing. Written Communication, 21(2), 171-200.

Spurlock, M. (Director). (2004). Supersize me [Documentary]. Kathbur Pictures.

Yamada, K. (2003). What prevents ESL/ EFL writers from avoiding plagiarism? Analyses of 10 North-American college websites. System, 31, 247-258.

\section{Appendix A}

Reference Types Used in the Reading Reference Grid

\begin{tabular}{lllll}
\hline & $\begin{array}{l}\text { Bounded/ } \\
\text { Documented } \\
\text { (linear } \\
\text { representations) }\end{array}$ & $\begin{array}{l}\text { Bounded/ } \\
\text { Undocumented } \\
\text { (partial) }\end{array}$ & $\begin{array}{l}\text { Unbounded/ } \\
\text { Documented } \\
\text { (partial) }\end{array}$ & $\begin{array}{l}\text { Unbounded/ } \\
\text { Undocumented } \\
\text { (pictorial } \\
\text { representations) }\end{array}$ \\
\hline Direct & DBD & DBU & DUD & DUU \\
Indirect & IBD & IBU & IUD & IUU \\
Quasi-Direct & QBD & QBU & QUD & QUU \\
Quasi-Indirect & QIBD & QIBU & QIUD & QIUU \\
\hline
\end{tabular}

\section{Appendix B}

\section{Sample Calculation of ARI: Candy}

The following table shows the number and kinds of references that Candy (an EL2 student) made in her written script. The first column shows the number of instances of each reference type that she made. The second column assigns a real value to each reference, and the third column indicates the total number that each reference type would be worth if it had been the best reference type possible. Because Candy has only one DBD, which is the best type of reference, the assigned value of this reference coincides with the total ideal value. She has only one DBU and scores a 2 for this type of reference because it is only partly correct (i.e., not fully bounded and documented). Candy had eight references in total, most of which were rated at the lowest level (1), but some of which were rated at a higher level (either 2 or 3). Candy's score of 1.5 tells us that she is not functioning at the lowest level of acceptable referencing practice, but is beginning to use references in an academically acceptable way. 


\begin{tabular}{lll}
\hline $\begin{array}{l}\text { Reference Types } \\
\text { and Assigned } \\
\text { Values* }\end{array}$ & $\begin{array}{l}\text { Number of } \\
\text { References }\end{array}$ & Calculated Values \\
\hline DBD (3) & 1 & $3 \times 1=3$ \\
DBU (2) & 1 & $2 \times 1=2$ \\
QBU (2) & 1 & $2 \times 1=2$ \\
DUU (1) & 2 & $1 \times 2=2$ \\
QiUU (1) & 2 & $1 \times 2=2$ \\
IUU (1) & 1 & 12 \\
Totals & 8 & \\
\hline
\end{tabular}

Average: $12 / 8=1.5$

*Note that only those reference types that appeared on Candy's written script are listed here. 